\title{
Money and the Economy
}

\author{
Nick Mayhew
}

Historians have often underestimated the role of money in the medieval economy. There have been a number of different reasons for this. In the first place, the recognition of coin as money has long been overshadowed by an awareness of its role within a network of socio-political relationships, at least partially expressed by the giving and receiving of gifts. Although such gifts were by no means restricted to offerings in coin, some scholars have felt that early medieval coins of the 6 th to 8 th centuries were more typically used as gifts rather than as an economic means of exchange. ${ }^{1}$ From the 9 th to the $13^{\text {th }}$ centuries, the role of coin as money also seemed for some to be overshadowed by payments in kind and labour rents, which loomed large in the documentary evidence. The manuscript sources that mention coin are often somewhat ambiguous, speaking of silver or gold, but even explicit mention of specific sums of $£$-s-d is sometimes explained away as really meaning goods to that value, rather than actual coins. ${ }^{2}$

However, many scholars have been ready to accept references to the use of coin as money at face value. M.M. Postan, writing as early as 1944, championed an interpretation of coins as money, dismissing the notion that coins mentioned in the documents might not be real. ${ }^{3}$ It should be recognized that England, the principal focus of this chapter, is unusually rich in medieval documentation. Yet those arguing for the reality of coin use there before the Norman conquest of 1066 have still encountered much resistance. For example, M.K. Lawson has argued that the chronicled levels of taxation under Æthelred II and Cnut are entirely plausible, but he has drawn heavy fire from sceptical

1 Grierson, "Commerce in the dark ages" was highly influential, though see now Naismith, Money and Power in Anglo-Saxon England, which provides a finely balanced assessment of the various uses of coin and fully recognizes its dominant monetary purpose without discounting its other social and political roles. Naismith's comments may be applied broadly, mutatis mutandis, before and after his specified period.

2 Le Goff, Money and the Middle Ages, while recognizing the widespread use of money in this period, retained the suspicion that coin in the documents might really only be "money of account". See, for example, pp. 29-30, 79, and 149 .

3 Postan, "The rise of a money economy", pp. 31-32. 
critics. ${ }^{4}$ Reginald Lennard's detailed analysis of Domesday Book found money payments far more frequently than he - or many other historians of his time - had expected. ${ }^{5}$ Nevertheless, the apparent rarity of coins in the documentary sources and in archaeological excavations encouraged the belief that coin use was restricted to an elite. Consequently, the discovery that early medieval coins were actually struck in millions came as something of a shock.

In the 1960s practical experimentation established that dies made by ancient and medieval methods were capable of striking thousands of coins before they broke or wore out. ${ }^{6}$ Meticulous die-study around the same time established that the rare surviving examples of medieval coins had been struck from a large number of different dies. ${ }^{7}$ Statisticians then calculated the total number of dies which might originally have been made for a particular issue. ${ }^{8}$ Debate continues about how many coins each die might actually have struck, but these approaches in concert provided the basis for estimates of the numbers of coins originally struck in the early Middle Ages. Even with wide margins of error, the order of magnitude for total coin production appeared far larger than anyone had previously imagined. The historical and archaeological establishment has taken some decades to come to terms with the size of the estimated early medieval currency and its implications for the wider economy, and the whole approach is still energetically criticized, particularly on the grounds that some dies may have been produced but scarcely used. ${ }^{9}$

4 Lawson, "The collection of danegeld and heregeld in the reigns of Aethelred II and Cnut"; Lawson, "'Those stories look true" "; Lawson, "Danegeld and heregeld once more"; Gillingham, "The most precious jewel in the English crown"; and Gillingham, "Chronicles and coins as evidence for levels of tribute and taxation in late tenth- and early eleventhcentury England".

5 Lennard, Rural England, 1086-1135, pp. 115, 120, and 176-80.

6 Sellwood, "Medieval minting techniques", pp. 57-65.

$7 \quad$ Metcalf, "How large was the Anglo-Saxon currency?", pp. 475-82.

8 Statisticians have devised increasingly sophisticated methods over recent years, but at its simplest the method recognizes that the more die-duplication which is observed in a particular issue, the closer the surviving sample comes to representing the total number of dies originally used. Conversely, the absence of die-duplication suggests the original number of dies was likely to have been much greater. All these methods offer a range of upper and lower limits within which the original number of dies used is likely to lie. See Esty, "Estimation of the size of a coinage", pp. 185-215; and Esty, "How to estimate the original number of dies and coverage of a sample", pp. 359-64.

9 Resistance to the idea of estimating original coin output from die-study is particularly strong among some ancient historians, while conversely documentary evidence from the later Middle Ages providing specific information about dies used and totals of coin 
From the 1980s, however, the use of metal-detectors in those countries where they are permitted has yielded a huge number of medieval finds, running into thousands every year, which provides powerful evidence that coins were indeed struck in millions and scattered widely over town and country and argues for their use as money on a very extensive basis. This important new source of quantitative historical information has been carefully recorded in some countries, providing important insights..$^{10}$ However, the situation has fluctuated over time, and though it is probably true in the broadest sense that money played a greater role in the later Middle Ages than in the early AngloSaxon period, it is not safe to assume that monetary development was steady or unbroken. The blossoming of a large and vigorous currency of silver sceattas in 8th-century England and the Low Countries marked a high-water mark of monetary exchange which was not to be reached again for several centuries, despite the presumption of rising population and the growth of towns. It seems likely that the availability of precious metal influenced the supply, use, and accidental loss of coins as much or more than other factors.

For example, changes in metal supply may have driven the shift from gold thrymsas towards silver sceattas in the course of the second half of the 7 th century. As gold became scarcer, it was gradually debased with increasing quantities of silver, creating "pale gold thrymsas" which were subsequently completely replaced by silver sceattas. It may be that this transition to lowervalue sceattas promoted a greater degree of monetization, permitting transactions involving smaller sums. ${ }^{11}$ But the interpretation of single-finds is as yet a young science: As well as demographic change and developing patterns of coin use, the value, or the actual physical size of coins, could have influenced

produced confirms that very large numbers of coins were struck per die. However, documented output per die did vary widely: mints remote from die-cutting centres continued to use dies for longer, and we may assume that strikers of small issues were more likely to underuse dies than large ones. See M. Allen, "Medieval English die-output", pp. 39-49.

10 Stray finds are being collected in the Netherlands on the Numis database: http://www .dnb.nl/over-dnb/nationale-numismatische-collectie/numis/index.jsp. For England, see the Portable Antiquities Scheme (PAS) data online, http://finds.org.uk, together with the Corpus of Early Medieval Coin Finds, http://www.fitzmuseum.cam.ac.uk/dept/coins/ emc. The collection of evidence of single-finds requires legal tolerance of the use of metal-detectors, albeit within prescribed limits. In countries where metal-detecting is totally prohibited, sites such as eBay suggest that single-finds continue to be recovered unrecorded.

11 However, D.M. Metcalf draws attention to the widespread dispersal of numerous "thrymsa/shilling" finds, which closely resemble the distribution patterns of sceatta finds. Metcalf, "Thrymsas and sceattas and the balance of payments". For pale gold thrymsas, see Metcalf, Thrymsas and Sceattas, vol. 1, pp. 42-47. 
the process of loss. Can we equate the loss of one thrymsa with that of, say, 12 sceattas, or should one chance loss equal another chance loss with no correction for value? ${ }^{12}$ Finding answers to questions of this sort will be necessary to establish an agreed methodology for the comparison of finds of different types of coins over time.

\section{Quantity Theory of Money}

Despite problems of interpretation, the sheer scale of medieval coin production argues strongly for their economic function, and an appreciation of quantities also opens the door to the potential of numismatic evidence for economic analysis. Whether in Irving Fisher's original version $(\mathrm{MV}=\mathrm{PT})$ or Alfred Marshall and John Maynard Keynes's Cambridge formulation $(\mathrm{M}=\mathrm{kY})$, the Quantity Theory of Money provides an important quantitative analytical tool. ${ }^{13}$ The application of Quantity Theory, especially in the form of a simple and direct relationship between the supply of money and the level of prices, has been much disputed. Nevertheless, it is worth recalling that Postan, who was far more interested in the effect of population on prices, nevertheless accepted what he called the "elementary algebra" of Quantity Theory. ${ }^{14}$ Nor should it be forgotten that the Quantity Theory of Money does incorporate the effects of population change, since demography plays a crucial role in the level of transactions (the Fisher version) and in GDP (the Cambridge version).

Quantity Theory also provides other important insights. The Velocity of circulation, sometimes termed "Income Velocity", relates to the rate at which the entire money stock needs to turn over each year in order to service the year's Transactions. It can be expressed according to Quantity Theory as V $=\mathrm{Y} / \mathrm{M}$. It is connected with, but not the same as the frequency with which money is used in society. Income Velocity provides useful clues to the extent of monetization in the economy, in that higher $\mathrm{v}$ numbers indicate a shortage of currency

12 This question might also affect the interpretation of later medieval finds, including varied metals and denominations.

13 Where $\mathrm{M}$ is the money stock, $\mathrm{V}$ is income velocity, $\mathrm{P}$ is the price level, $\mathrm{T}$ is the level of transactions, $\mathrm{k}$ is the demand for money to hold, and Y represents GDP. Fisher, The Purchasing Power of Money; Skidelsky, John Maynard Keynes, pp. 419-21; Flynn, "Use and misuse of the quantity theory of money in early modern historiography", pp. $382-418$. The theory is thus about more than just money and prices, but embraces the whole economy and the nature of monetary circulation.

Postan, "Note", p. 78. 
relative to the needs of the economy. ${ }^{15}$ Domesday Book provides the raw data which permit an approximation of the size of the late 11th-century economy $(\mathrm{Y}){ }^{16}$ while numismatists have made estimates of the likely size of the currency $(M)$ at this time. Estimates of Velocity $(\mathrm{V}=\mathrm{Y} / \mathrm{M})$ may then be suggested, yielding notably high numbers (8) compared, for example, with estimated $\mathrm{V}$ in 1300 (5.5).These abstract numbers may be interpreted to suggest that the business of the economy c.1086 could only have been accomplished with the assistance of various non-monetary expedients such as payments in kind, or labour or service rents, in addition to cash payments. This would support the notion that early medieval England was less thoroughly monetized than in the later Middle Ages. Over the long term it can be seen that English V falls fairly consistently from early medieval through to early modern times. ${ }^{17}$ This perhaps surprising observation reflects the fact that it is rising money supply (or stock) which fuels increasing monetization, rather than a higher turnover of the money supply. ${ }^{18}$ However, the higher 16 th-century v numbers correspond with the deflationary pressures of that time first identified by J.R. Wordie. ${ }^{19}$

The Cambridge version of the Quantity Theory developed two variations on the Fisher Identity. It replaced the unquantified level of transactions $(T)$ with GDP as a measure of the amount of work which the money supply needed to perform to serve the economy as a whole. ${ }^{20}$ While it must be granted that even modern estimates of GDP are not precise, and that historical estimates of GDP can only be approximations, economic historians have applied themselves to the task of estimating GDP with skill and energy. England and Wales (and, after 1700, Britain) have now been supplied with an unbroken run of carefully researched GDP estimates beginning in $1270 .{ }^{21}$ It may be reasonably pointed out that few countries are as well supplied with economic data as England, but a technique has been advanced which permits the estimation of GDP on

\footnotetext{
15 Mayhew. "Modelling medieval monetisation", pp. 68-71.

16 Snooks, "The dynamic role of the market in the Anglo-Norman economy and beyond, 1086-1300"; Mayhew, "Modelling medieval monetisation"; Dyer, "A note on the calculation of GDP for 1086 and 1300"; Walker, "National income in domesday England"; and Harvey, Domesday, pp. 162-65.

17 Mayhew, "Population, money supply and the velocity of circulation in England, 13001700 ", pp. 244 and $252-55$.

18 Note that Income Velocity records the number of times the whole money stock would need to turn over, not the frequency of money payments in the economy.

19 Wordie, "Deflationary factors in the Tudor price rise", pp. 32-70.

20 GDP is conventionally expressed by the symbol Y. For the second variation, the replacement of $\mathrm{V}$ by the symbol k, representing "demand for money to hold", see below, p.225, note 68 .

21 Broadberry et al., British Economic Growth.
} 
the basis of population levels and basic average wage data. ${ }^{22}$ In principle, this approach could generate GDP estimates from regions or countries less well provided with data than Britain.

\section{Money and Prices}

Alongside Britain's remarkable GDP data, medieval England also provides the best information on commodity prices. ${ }^{23}$ Of course, perhaps the principal use of Quantity Theory is as an explanation for the behaviour of prices. Put simply, it is argued that prices rise and fall with the available, effective money stock. This argument has a long history, and has been fiercely contested. In recent times this "monetarist" argument has been associated in particular with the Milton Friedman school, but it should also be recognized that Keynes accepted the basic tenets of this theory. The argument between right- and left-wing economists today hinges on the wisdom or otherwise of deficit financing to increase money supply or austerity to restrict monetary growth, not on the principle that more money tends to raise prices while money shortage tends to restrict it. Perhaps the most obvious contemporary demonstration of the importance of money on the behaviour of prices is provided by the case of "Quantitative Easing". After the banking crisis of 2007-2008 crippled the national and international banking sector, governments - the US and UK first, but subsequently also the wary European Central Bank - deliberately created money in order to avoid an international liquidity crisis. ${ }^{24}$

However, economists on the left and right accept the power of money to influence prices and the role of low-level inflation in the promotion of economic growth. Nowadays the government instructs the Bank of England's

Bairoch, "Estimations du revenue national dans les sociétés occidentales pre-industrielles et au XIXe siècle".

23 Rogers, A History of Agriculture and Prices in England, 1259-1793; Farmer, "Prices and Wages [1042-1350]"; Farmer, "Prices and Wages, 1350-1500"; Phelps Brown and Hopkins, "Seven centuries of the prices of consumables"; R. Allen, https://www.nuffield.ox.ac.uk/ people/sites/allen-research-pages/; G. Clark, IIs H List of Datafiles of Historical Prices and Wages, http://www.iisg.nl/hpw.

24 The initial reluctance of the European Central Bank to employ Quantitative Easing, in contrast to the US and the UK, created an interesting real-life experiment. It became clear that growth returned to those economies which did employ QE. Eventually the European Central Bank followed suit and growth returned there too. Of course the real-life experiment could not exclude other possible extraneous factors. Nor is it certain that the financial technique chosen to deliver QE was necessarily ideal. 
Monetary Policy Committee, which sets interest rates, to target an inflation rate of 2 per cent per annum. Scarcity of money is associated with recession or even economic depression, while excess monetary growth generates damaging levels of inflation. In the context of medieval Europe, it is generally the case that money was always relatively scarce, though this scarcity was occasionally alleviated by bursts of increased mining and minting activity. The first such burst in the Middle Ages is marked by the astonishing numbers of sceatta finds from England and the Low Countries dated to the late 7th through mid-8th centuries, though it has not been possible to associate this explosion of minting with any specific mining activity. Perhaps it was fuelled at least in part by the conversion of late antique non-monetary silver to coin. Subsequently important mines at Melle in France and Rammelsburg and the Harz in Germany certainly fed periods of increased minting, while the Viking invasions brought silver from central Asian mines into Europe. It is, however, noteworthy that the English stray-find evidence suggests that 8th-century levels of coin loss were not equalled till the late 12th- and 13thcentury monetary boom triggered by mining in Saxony and then Bohemia. ${ }^{25}$ This boom may be associated with a marked and prolonged rise in prices, and with a commercial revolution which brought profound changes to the European economy. ${ }^{26}$

\section{Factors Influencing the Supply of Bullion}

While the supply of bullion was governed by the discovery and exploitation of mines, the allocation of the resulting monetary metals to any particular national or regional economy depended on the balance of payments. In the case of England, which never had any really prolific silver or gold mines, the supply of monetary metals depended on the balance of trade. P.H. Sawyer first drew attention to the wealth of 11th-century England founded on wool exports, ${ }^{27}$ while D.M. Metcalf has argued convincingly that the presence in England of very large numbers of sceattas from the Low Countries suggests that by the late 7 th century England already enjoyed a healthy positive balance of

\footnotetext{
25 For the coin find data compared over centuries see PAS database; for silver mining see Spufford, Money and Its Use in Medieval Europe, pp. 109-31.

26 For the commercial revolution, see Britnell and Campbell, A Commercialising Economy; for increasing monetization, see Mayhew, "Modelling medieval monetisation".

27 Sawyer, "Wealth of England"; and Sawyer, The Wealth of Anglo-Saxon England.
} 
trade, probably based on substantial wool exports. ${ }^{28}$ The dominance of wool in English trade was to be a permanent feature throughout the Middle Ages, though the imposition of export tax on wool boosted English cloth exports at the expense of raw wool in the second half of the 14 th and the 15 th centuries. ${ }^{29}$

Countries with a less favourable balance of trade had either to accommodate themselves to a more restricted money supply or to strike more coin from each pound of metal, which necessarily involved a reduction in the weight or fineness of each coin. Fixing the appropriate intrinsic content for the coinage of any particular country was not easy. If it was too high, the resulting currency would be "strong", and prices stable and relatively low, but the scarcity of money in the economy would inhibit trade. Yet if the coinage was too "weak", with a low intrinsic content, prices would rise. Deciding the strength or weakness of the coinage effectively set the price in new coin at which the mint could buy silver or gold bullion. Governments would also need to be aware of the strength or weakness of the coinage of neighbouring competing mints. This would determine international exchange rates and influence the levels of imports and exports. Consequently, fixing the strength of the coinage was one of the most difficult decisions governments had to make, yet it had profound implications for the whole economy. Determining the appropriate intrinsic content was thus analogous with the fixing of interest rates today. Adjustments in both cases influence the availability of money, which in turn affects the level of domestic prices, the exchange rate, and the growth or contraction of the whole economy.

\section{Estimating the Supply of Money}

If money was indeed playing a significant role in economy and society at this time, it is important to establish some idea of how much of it was in use. Fortunately numismatic and monetary evidence is particularly amenable to the quantitative analysis which is so important for the study of the economy. From the 13th century England possessed an unrivalled run of mint accounts providing documentary evidence for mint output in an almost unbroken run until the present day. ${ }^{30}$ This material makes England an ideal case-study.

28 Metcalf, "Thrymsas and sceattas"; Metcalf, Thrymsas and Sceattas, vol. 2, for continental sceattas; Op den Velde and Metcalf, Sceattas of Series D; and Metcalf and Op den Velde, Sceattas of Series E.

29 Lloyd, The English Wool Trade in the Middle Ages; and Lloyd, "Overseas trade and the English money supply in the fourteenth century".

30 Allen, Mints and Money in Medieval England, appendix C, pp. 404-24; and Challis, A New History of the Royal Mint, appendix 1, pp. 673-98. Though the English mint data is 
However, although mint output data is an invaluable aid for the estimation of money supply, it has to be distinguished from estimates of the stock of money available at any particular time and place. This is because coin, once issued by the mint, does not necessarily remain permanently as part of the currency. It may be carried abroad in war or trade or removed from circulation, whether temporarily or permanently in hoards or accidentally through wear or casual losses. The loss of bullion through wear in use or deliberate clipping is not necessarily apparent until the worn coin is recoined. Mints often recalled all or part of the coin in circulation, in order to melt, recoin and re-issue it. These periods of recoinage are especially useful insofar as they brought a large proportion of the total currency into the mint. However, recording totals of mint output can be only the first step in attempts to estimate the size of the available currency. Coin hoards and single-finds provide information about specific coins in use, which can be combined with the mint output data to provide an estimate of national or regional money stock at some particular moment.

For medieval England, this process of estimating the size of the currency began in 1974 and has been subject to a number of improvements since. Martin Allen has pointed out that Mayhew's early estimates omitted groats, halfpennies, farthings, and output from provincial mints, and failed to allow for the role of Scots and Irish coin in England. ${ }^{31}$ Accordingly, Allen's estimates for 1319 and 1332 rise significantly above the numbers suggested by Mayhew for the first quarter of the 14th century. However, until 1367 when the Scottish currency began to diverge from the English, an effective "Sterling area" operated across England, Wales, Scotland, and Ireland, and the currency attributed to England effectively supplied the whole Sterling area. The share of this common currency specifically in use within England (and Wales) c.130o has been estimated at about 83 per cent of the total, so Allen's most recent estimates of what he terms the "English currency" might be reduced by 17 per cent to derive a total

probably the best, much is also available for western Europe. For the Low Countries, see especially the extensive bibliography of John Munro in Armstrong, Elbl, and Elbl, Money, Markets and Trade, pp. 11-40. For France, see Bompaire and Dumas, Numismatique Médiévale; Miskimin, Money, Prices and Foreign Exchange in Fourteenth-Century France; Miskimin, Money and Power in Fifteenth-Century France; Sussman, "Missing bullion or missing documents"; Miskimin, "Missing bullion or missing documents: a rejoinder"; and Day, "The great bullion famine of the fifteenth century" for a later medieval European overview. Note that Sussman is sceptical about bullion famine.

31 Mayhew, "Numismatic evidence"; Allen, Mints and Money, pp. 317-45. Allen's most recently revised estimates appear in "Sterling area". 
TABLE 9.1 Estimated total value of coins in circulation in the British Isles

\begin{tabular}{|c|c|c|c|c|c|c|}
\hline Date & Ag Min & $\operatorname{Ag} \operatorname{Max}$ & Au Min & Au Max & $\begin{array}{l}\text { less 17\% } \\
\text { Ag Min }\end{array}$ & $\begin{array}{l}\text { less 17\% } \\
\text { Ag Max }\end{array}$ \\
\hline 1290 & 1.064 & 1.4185 & & & 0.8831 & 1.1773 \\
\hline 1299 & $0.85^{2}$ & 1.067 & & & 0.7071 & 0.8856 \\
\hline 1310 & 1.47 & 1.8425 & & & 1.2201 & $1.5^{292}$ \\
\hline 1319 & 1.867 & 2.414 & & & 1.5496 & 2.0036 \\
\hline 1332 & 1.5625 & $2.05^{1}$ & & & 1.2968 & 1.7023 \\
\hline 1351 & $0.5^{21}$ & 0.563 & 0.1 & 0.15 & 0.4672 & 0.5324 \\
\hline
\end{tabular}

Source: M. ALlen, "Sterling AREA" (Less-17\% DAtA AdDED by AUthor) (IN $£$ MILLIONS)

for England alone in the early 14th century. ${ }^{32}$ As this very "rule of thumb" adjustment makes plain, it should never be forgotten that these estimates are just that - estimates - despite the appearance of accuracy suggested by specific figures offered to several decimal places derived from the process of calculation.

A fundamental consideration affecting estimates of the currency concerns the appropriate allowance for the rate at which coins were withdrawn or lost from circulation. This factor, known as wastage, probably eroded the total original output at variable rates of between about 1 and 4 per cent per annum. Allen also improves on Mayhew's earlier estimates by prudently offering maximum and minimum estimates of total currency, though Mayhew's single-point estimates generally fall within or close to Allen's parameters. Both authors agree that silver coinage peaked in the first quarter of the 14th century but fell precipitously between 1330 and 135 .

From the mid-14th century English recoinages no longer demonetized earlier issues, which makes it more difficult to estimate the money stock. The recoinage output provides a useful indication, but the amount of earlier coin remaining in the currency is uncertain. Calculations are also complicated by the introduction of a wider range of denominations in gold and silver, making it more difficult to determine how far hoards and stray finds are providing us with a representative sample of the currency as a whole.

Table 9.2 prompts a number of observations. The dominance of gold and the decline of silver are notable in 1377 and 1422 . The 1422 and 1470 estimates

$3^{2}$ Allen, "Sterling area". Thus Allen's peak year of 1319 would see his "English" estimate $£ 1.867 \mathrm{~m}$ to $£ 2.414 \mathrm{~m}$ reduced to about £1.6m to £2m for England alone. 
TABLE 9.2 Available stocks of gold and silver

\begin{tabular}{lllllll}
\hline Date & Ag Min & Ag Max & Au Min & Au Max & $\begin{array}{l}\text { Total } \\
\text { Min }\end{array}$ & $\begin{array}{l}\text { Total } \\
\text { Max }\end{array}$ \\
\hline 1377 & 0.22 & 0.74 & 1.20 & 1.65 & 1.42 & 2.39 \\
1422 & 0.10 & 0.15 & 1.12 & 1.20 & 1.22 & 1.35 \\
1470 & 0.35 & 0.45 & 0.40 & 0.50 & 0.75 & 0.95 \\
1544 & & & & & 1.00 & 1.50 \\
\hline
\end{tabular}

SOURCE: M. ALLEN, "STERLING AREA"

are both informed by recent recoinages, though the estimate for 1377 , when the range between possible maximum and minimum estimates is particularly wide, is complicated by the survival of old coins from before the 1351 recoinage, and by uncertainties about the likely levels of wastage. Allen and Gary Oddie have shown that the latter was liable to vary uncertainly over time. ${ }^{33}$ Nevertheless, actually varying wastage rates can yield a hypothetical average over a number of years. Allen uses such averages in his calculation of the 1377 figures, ${ }^{34}$ and Mayhew has calculated with possible average levels of wastage between the relatively firmly based benchmarks indicated by recoinages. ${ }^{35}$ Nuno Palma also adopts this approach. ${ }^{36}$ Averages, by definition, are unlikely to be precisely accurate in any one year, but may nevertheless present a picture which is broadly true over a number of years.

This is not the place to argue over different estimates of the money stock in England, but Allen has shown how critical examination of existing estimates can improve our knowledge, and the process will continue as new find evidence and new analytical techniques emerge. The surviving English documentary evidence for mint production, together with the information from coin hoards and single-finds, is unusually strong, but much continental data does

33 M. Allen and Oddie, "Revised estimates of the English silver currency, 1282-1351", pp. $245^{-52 .}$

34 Allen, Mints and Money, pp. 332-36.

35 Mayhew, "Quantity theory in historical perspective", pp. 62-96. Mayhew's annual money stock estimates after the Black Death generally fall within or close to Allen's numbers, though his figures here for before the event look too low. See also Mayhew, "Prices in England".

36 Palma, "Reconstruction of annual money supply over the long run". 
exist, and stray finds are increasingly recognized as important in several countries on the European mainland. ${ }^{37}$

As well as the size of the total money stock, some consideration should also be given to its composition. In the course of the 7 th century gold coinages in northern and western Europe gave way entirely to silver pennies. From the 8th to the 13th centuries the money of Europe was overwhelmingly silver of sometimes variable fineness, while Middle Eastern coinages consisted almost exclusively of gold and copper. ${ }^{38}$ However, in the course of the 13th century, European mints began to introduce gold coinages alongside their established silver coins. Florence in 1252 and Venice in 1284 both launched highly successful gold coins which were to dominate the monetary history of later medieval Europe. In northern Europe, the advantages of larger denominations were quickly recognized, but attempts to introduce larger silver grossi/groschen/ groats alongside new high-value gold coins needed time to take root. Henry III in England and Louis IX in France each launched short-lived gold coins; Edward I's groat was equally unsuccessful. The French gros tournois, however, did find acceptance, perhaps because French pennies (deniers tournois) were too much debased to continue to function as a convenient vehicle for larger transactions. The English sterling penny, on the other hand, enjoyed wide acceptance in international trade across northwestern Europe, so the English groat in the late 13th century seemed less necessary.

However, the trend towards larger silver coins and high-value gold coins gathered momentum, and these coinages came to dominate the currency of western Europe from the 14th century onwards. ${ }^{39}$ This development was not entirely trouble-free. The additional sophistication of the monetary systems brought difficulties of its own. Managing the exchange rates of different silver coinages, though complicated by the variable weights and finenesses involved, did at least require the comparison of silver with silver. Managing the relative values of gold and silver created a whole new layer of complexity. While it may initially have been hoped that gold coin would serve the needs of high-value international trade, leaving silver at home to be used in day-to-day transactions, the reality proved very different. International comparison of different gold - silver ratios meant that any country was liable to see one metal carried away, attracted by a higher price elsewhere, while the other tended to flow

37 For mint output, see note 30 above.

38 Watson, "Back to gold-and silver", pp. 1-34.

39 Mate, "The role of gold coinage in the English economy", argues for the profound significance of the introduction of gold coins in England. For further consideration of the implications of England's bias towards gold coinage, see below, pp. 224-5. 
inwards, as it was more highly valued locally. England, for example, tended to undervalue silver, so foreign merchants preferred to settle debts in England with gold. The contrast is visible in the English mint output records, which for most of the later Middle Ages show that gold coin was being struck much more plentifully than silver. ${ }^{40}$ Parliament petitioned repeatedly for more halfpennies and farthings to be struck, but the sources show that pennies too were in scant supply, while total silver mint output, including groats and half-groats, was paltry compared with the totals of gold struck..$^{41}$ If different denominations and different monetary metals circulated differently, as is suggested by the varying degrees of wear exhibited on the coins, it may be that we need to take account of the composition of the money stock as well as its total size. From the 14th century onwards Europe operated a bi- or even tri-metallic monetary system. Moreover, although credit transactions eventually needed to be settled in coin of some description, the fundamental importance of credit for both international and local trade reminds us that medieval money was not always metallic.

\section{Credit}

For the Middle Ages, it is not unreasonable to regard money and coinage as synonymous, but any consideration of money in the economy must take account of the role of credit in its various forms. ${ }^{42}$ Whether cash was advanced from lender to borrower, or goods sold in advance of the actual cash payment (or some part of it), or money transferred or lent by bills of exchange or bonds or recognizances, there can be no doubt that credit in its various forms was essential for the transaction of medieval business. International merchants relied on it, as the failure of the bullion laws of the 1420 and 1430 s demonstrated. The

40 Challis, Royal Mint, appendix 1. The 1420 s reveal a noteworthy exception, when London and the English mint in Calais struck very large amounts of silver which came to the English mints in flight from the runaway debasements afflicting the Flemish, French, and Burgundian mints.

41 For Parliamentary petitions, see Allen, Mints and Money, pp. 36o-64. For the shortage of pence or money generally, see, for example, Kirby, The Plumpton Letters and Papers,. pp. 34-35 (no. 11): "Impedit omne forum carentia denariorum". For similar references in the Paston Letters, see also Mayhew, "The monetary background to the Yorkist recoinage of 1464-71", pp. 71-72.

42 Postan, Medieval Trade and Finance, ch. 1 and 2, remain invaluable introductions. See also Gaspar Feliu, this volume, for credit in Catalonia. 
wool and cloth trades depended on credit from before the clip to the export of raw wool or the sale of domestic cloth at home. Italian banking houses specialized in it, and the English Exchequer operated an advanced system of tallies, which economized on the use of coin. ${ }^{43}$ Edward I required his sheriffs and the court of Chancery to assist in the recovery of debts over 40 shillings, while manorial courts were busily engaged in the pursuit of those owing lesser sums. The records of the Borromei are full of credit, and small country merchants spent much time and energy extending credit or chasing repayment. Those in regular contact with one another allowed mutual debts to accrue over years before settling up at an occasional reckoning. ${ }^{4}$

Although all historians agree on the importance of credit, there remains a fundamental disagreement over whether lending grew to compensate for monetary shortage or contracted as money became scarce. Many have argued that the ubiquity of medieval credit made fluctuations in the money stock economically insignificant, while others assert that credit shrinks when money becomes scarce, so a shortage of coin would have a severe impact on business.

Methods of economizing on the use of coin may well have become more important when money was scarce, and these strategies would all have raised the Velocity of the circulation. Velocity has been shown to fall over the long run, as rising $\mathrm{M}$ permits a greater volume of business to be transacted, but high $\mathrm{v}$ numbers suggest periods of monetary distress, when scarcity of money stimulates means of managing without coin. Nevertheless, despite the use of such expedients, the growth of business was fundamentally restrained by the money supply. Credit sales or cash advances were limited by the availability of coin, as demonstrated by Pamela Nightingale's study of Chancery certificates of debt. ${ }^{45}$ Although this argument has been energetically contested by Jim Bolton, Chris Briggs has found no evidence in manorial courts of lending increasing in periods of coin shortage, while recent work by Matthew Stevens

43 The use of tallies was a regular feature of the Exchequer's accounting system with the sheriffs: see Dialogus, xliv; Jenkinson, "Exchequer tallies"; and Jenkinson, "Medieval tallies, public and private". But they were unpopular with those who were paid with them: see Mayhew, "Yorkist recoinage", p. 70, citing Piers Plowman; and Maddicott, "The English peasantry and the demands of the crown", p. 12.

44 Dyer, A Country Merchant, p. 98. For the Borromei, see Bolton, Money in the Medieval English Economy, pp. 246, 285-87, and 290-93.

45 Nightingale, "Monetary contraction and mercantile credit in later medieval England"; Nightingale, "Knights and merchants"; Nightingale, "The English parochial clergy as investors and creditors in the first half of the fourteenth century"; and Nightingale, "Gold, credit and mortality". 
on the Court of Common Pleas offers strong support for Nightingale's interpretation. ${ }^{46}$

\section{Population in Quantity Theory}

It is sometimes imagined that the Quantity Theory of Money fails to take account of perhaps the most powerful of economic factors - demographic change. The simple relationships between land and labour, and between mouths to feed and hands to work, rightly dominate our understanding of preindustrial societies. Compared with these fundamental realities, monetary factors can only seem secondary. Indeed, compared with the inescapable realities of birth and death, money and prices look like superficial considerations. They are, however, powerful economic factors. Moreover, the Quantity Theory does take account of demographic change, which is included in the Transactions element of the Fisher version, or in the Y or GDP in the Cambridge version, since any attempt to estimate medieval GDP depends above all on a prior estimate of population.

However, the introduction of population into Quantity Theory analysis has surprising results. It was Wordie who first pointed out that rising population, by increasing Transactions (or GDP), would tend to deflate prices rather than inflate them. ${ }^{47} \mathrm{~A}$ larger population creates more transactions, (a larger GDP), which makes greater demands on the available money stock. Moreover, recent work on English economic growth has established that output grows as much as or more than population, while John Langdon and James Masschaele saw entrepreneurial activity driving population growth. ${ }^{48}$ If these insights are sound, "supply" in the form of increased economic output exceeded "demand" generated by growing population. In short, rising population increases production more than it increases demand. The simple assumption that rising population raises prices by increasing demand more than supply turns out to be mistaken. Instead, it could be argued that rising $\mathrm{M}$ inflates prices, while moderate inflation promotes economic growth, ${ }^{49}$ which in turn permits demographic

46 Bolton, "Was there a 'crisis of credit' in fifteenth-century England?"; Bolton, "Reply to Pamela Nightingale's 'A Crisis of Credit'”; Briggs, Credit and Village Society in FourteenthCentury England; Stevens, "London creditors and the fifteenth-century depression".

48 Both cited by Mayhew, "Prices in England", pp. 22-25.

49 Munro, "Profit inflation". 
growth..$^{50}$ Thus money, and prices expressed in money, though intrinsically far less significant than the vital driving forces of life and death, do nevertheless directly influence the great demographic and social realities.

Economists must perhaps share some of the blame for the misconception that monetary effects are not "real". They often go to great lengths attempting to strip out monetary effects, in order to reveal the "real" underlying factors. Thus nominal prices - the sums in which prices and debts were actually recorded and paid - are sometimes set aside in favour of "real" prices. Such conversions are perfectly legitimate in order to compare prices between different countries or periods, if the nominal prices are deflated or inflated by the appropriate cost of living index. However, the widespread practice of converting nominal prices in line with coins' intrinsic silver content is fundamentally flawed. ${ }^{51}$ In the first place, converting to silver weight assumes that silver provides a reliable, constant yardstick. In fact, the value of silver varies over time and from place to place. Secondly, such conversions are generally based on the legal weight of freshly minted coins, although actual transactions usually involved coins of variable weight, which could fall significantly below the legal weight of newly minted coins. ${ }^{52}$ Converting sums of money to their silver weight equivalent is thus historically mistaken. ${ }^{53}$

Modern scholars' emphasis on the intrinsic content of coinage is also misleading in that it fails to recognize the role of medieval governments in setting the value of currency. ${ }^{54}$ Governments - the king or prince, often in agreement with Parliament and with the advice of merchants, goldsmiths, and mint staff first established the quantity of coin to be struck from a pound or mark weight of pure bullion (the gross mint price). Thus a monetary pound (£) of 240 pence was to be struck from a pound weight (lb) of silver. On each pound the crown

50 Note, however, that rising population may restrain wages, despite rising prices. Such hardship imposed on the labouring class may eventually bear down on aggregate effective demand.

51 For example, Robert Allen's otherwise invaluable databases of international prices and wages succumb to the temptation to offer simplistic conversions of values according to theoretical silver weight. Allen, Consumer Price Indexes; Allen, "The great divergence in European wages and prices from the Middle Ages to the First World War"; and Allen, "The high wage economy and the Industrial Revolution", esp. pp. 9-10.

52 Although gold coins in payment may have been weighed, silver coins generally passed at their nominal value unweighed unless they were visibly clipped.

53 Mayhew, "Money in England from the middle ages to the nineteenth century".

54 Desan, Making Money, demonstrates clearly the extent to which money is the product of government action. For the continental perspective, see Fox and Ernst, Money in the Western Legal Tradition. 
took a profit (seigniorage). The cost of actually making the coins (mintage) was also deducted, leaving the rest (the net mint price) to be returned to the supplier of the bullion. However, the gross mint price depended fundamentally on the weight and fineness (purity) of the coins. If government decided to strike slightly lighter coins, more than 240 pence could be made from each pound weight. In the same way, if the coins were struck of slightly less pure silver, then a pound weight of pure metal would yield more than 240 pence.

The government determined the weight and purity of the coins, but it also decreed their nominal face value. Over the course of the later Middle Ages the English government halved the weight of the penny from about 22 grains of sterling silver to just under 11 grains, ${ }^{55}$ but the nominal face value of each issue remained unchanged at a penny, 240 of them still making a monetary pound sterling $(£)$. Since prices, rents, and debts were all denominated in nominal pounds $(£)$, shillings $(\mathrm{s})$, and pence $(\mathrm{d} \text {, from denarius) })^{56}$ these successive weight reductions meant sellers, landlords, and creditors had to accept less silver weight in their transactions than they had received before the coinage alterations.

There are various reasons why they did so. First, the strength of the English monarchy and its long-standing regalian right to control the coinage stretched back over centuries. Foreign coin was effectively excluded, and any short-lived feudal mints had been brought back under central royal control. Parliament attempted to exert some measure of influence, occasionally extracting an undertaking from the crown not to alter the money again without parliamentary agreement, but the royal prerogative remained paramount. The law consistently supported the crown's ruling on the coinage and enforced it in the courts. Second, these occasional reductions in the weight of the currency responded to a recognized shortage of coin in the country at large. Weight reductions permitted the production of more coin from the same amount of bullion. Third, the value of silver throughout Europe was rising over the course of the later Middle Ages as silver production from the mines went into decline. The weight reductions effected by the English mint did no more than recognize the rising value of the metal. ${ }^{57}$ Moreover, these weight reductions were so moderate and so gradual that much old coin had already become worn in decades of use,

55 The penny of about 22 grains was reduced to 18 grains in 1351, 15 grains in 1412, 12 grains in 1464, and under 11 grains in 1526. See Challis, Royal Mint; Allen, Mints and Money; and, for a tabular presentation of the detail of the process, Hotson, Respectable Banking.

$5^{6}$ The mark of $13 \mathrm{~s} 4 \mathrm{~d}$ (=16o pence) was also commonly used.

57 Indeed, it could be argued that the English mint responded too little and too late to the rising price of metal. See Mayhew, "Monetary policy". 
so that the newly decreed weights were often close to those of many of the old coins already in use. Finally, the acceptance of coin at face value without weighing each transaction was established practice, and extremely convenient. No doubt sellers scrutinized the coin they were offered carefully, and visibly clipped money could certainly be rejected. Also, gold coin was more likely to be individually weighed, since its high value would justify the time and trouble taken. But for the most part, by well-established custom, silver was accepted by tale, that is, at face value.

Yet perhaps the most telling evidence that the English weight reductions were widely accepted is provided by the behaviour of prices. As a rather puzzled Thorold Rogers observed, the reductions in the weight of the English currency did not prompt any discernible rise in prices. ${ }^{58}$ Even though sellers were required by law to accept the new money at face value, they could easily and silently have enhanced their prices to restore their silver receipts to their former weight. No such price response is apparent.

In this respect, the English experience differed somewhat from that elsewhere in much of Europe. Continental (and Scottish) debasements reduced not only the weight of the coinage, but also the purity of the coinage metal. ${ }^{59}$ They also occurred more frequently. It is arguable that while English kings met the costs of government and war from the proceeds of taxation, continental rulers resorted to fiscal debasements. This did far more than simply recognize the rising market price of coinage metals. More extreme debasements generated greater resistance, and the palpable injustice of settling strong money debts in weak money was recognized in continental courts.

Heavier debasements in Scotland and on the continent did inflate prices, though this effect is often difficult to distinguish from other factors bearing on prices, most obviously the annual harvest. The effects of debasement also took time to develop: John Munro has suggested a two-year time lag. ${ }^{60}$ Consequently any price changes were unlikely to be fully in proportion to the debasement. By contrast, exchange rates do respond quickly to debasement.

$5^{8}$ Rogers, Six Centuries of Work and Wages, pp. 341-42. Rogers notes that Adam Smith saw no significant rise in prices after these weight reductions in the coinage.

59 A third method of debasement also sometimes employed was to enhance the nominal value of existing coins.

6o Munro, "Technology and economics of coinage debasements", pp. 23 and 25 and table 1.2. Information about debasement took time to filter through, while new coins also had to spread through the currency. If debasement merely reflected the rising price of bullion it might not result in price change at all. Most obviously variable harvests make discerning price changes attributable to debasement highly complex. 
News of published mint prices spread quickly abroad, and merchants adjusted international exchange rates accordingly. ${ }^{61}$ Such debasement acted exactly like a modern devaluation, making exports cheaper but imports dearer.

For all these reasons, government decisions about the mint price offered for coinage metals could have a profound, though not always proportional, impact on the economy as a whole. Sometimes the consequences of government decisions were not fully appreciated. Altering mint prices could disrupt the relative valuation of gold and silver, prompting a flow of one metal into the country and a loss of the other metal to neighbouring mints, which valued it more highly. For example, it is noteworthy that the English mints often attracted one metal at the expense of very low production rates for the other. ${ }^{62}$ In the later Middle Ages England usually attracted gold at the expense of silver, resulting in a marked imbalance in the currency as a whole.

The relatively plentiful provision of gold has prompted the observation that England's total money supply in the later Middle Ages seems to have been fully adequate for the needs of the much-reduced post-plague population. ${ }^{63}$ This in turn would throw doubt on the argument that the low prices characteristic of England's later medieval recession were driven by monetary shortage. However, it may be that the extreme shortage of silver coinage could have depressed prices, despite the availability of gold. Only 24.4 per cent by value of the total documented English mint output of the period 1344 to 1509 was in silver, while the remaining 75.6 per cent was in gold. ${ }^{64}$ Although gold fractions were struck, even the quarter noble had a face value of is $8 \mathrm{~d}$., five times the typical postplague daily wage of $4 \mathrm{~d}$. From the 1470s the angel replaced the noble as the gold coin worth $6 \mathrm{~s} 8 \mathrm{~d}$., but the half angel, worth $3 \mathrm{~s} 4 \mathrm{~d}$, was then the smallest gold denomination. Moreover, the supply of gold fractions was probably much more limited, since the terms of the mintmasters' remuneration favoured the production of higher-value pieces. This bias in favour of striking higher value coins also affected the silver issues, in that groats and half groats were more

61 See Spufford, "Debasement of the coinage", pp. 63-86. The falling exchange rate would raise the cost of imported goods. Spufford found that both the exchange rate and consumer prices responded to the net mint price for bullion offered to merchants, rather than to the gross mint price, which would have revealed the actual fineness and weight of the new issues.

62 See the mint output figures, note 30 above.

63 Allen, "Sterling area".

64 In comparison, silver made up 43.4 per cent of the total currency in the period 1509-1542 and 64.1 percent in 1559-1649. Mayhew, "Prices in England", p. 28, table 4. See also Martin Allen's assessment of the dwindling share of silver in the fourteenth-century currency in "Transformation of the English coinage", table 9.1. 
readily struck than pence or halfpennies. The farthing disappeared altogether as successive weight reductions in the coinage made them too small to be conveniently handled.

Unlike most of the rest of Europe, in the Middle Ages England did not strike coin in billon (i.e., heavily debased silver) or copper. Indeed scholars on the continent have argued that an adequate provision of smaller denominations was essential for the deeper monetization of the economy. ${ }^{65}$ Although English historians would probably argue that later medieval England was in fact thoroughly monetized, the structure of English denominations was certainly not favourable to the conduct of most day-to-day transactions.

In this connection, it is helpful to recall that Maynard Keynes preferred a version of Quantity Theory which replaced estimated Velocity with its inverse, "demand for money to hold", or k. This drew attention to the effect of money withdrawn from the active money stock through savings, hoarding, or simply holding it ready for opportunistic purchases. In periods of economic or political crisis the amount of such "withdrawn" money will have increased, reducing liquidity for the rest of the economy. It may also be observed that some types of money are more likely to be withdrawn than others, and that in particular gold coins may have circulated less actively than silver. ${ }^{66}$ In terms of the oft-cited functions of money, gold serves well as a store of value, while silver has historically provided a better means of exchange. Indeed, some recent research on the early modern period suggests that silver supplies drive prices, rather than gold. ${ }^{67}$ This may help to explain the prolonged periods of sluggish prices which are notable particularly in the 15th and 18th centuries, when gold dominated the money supply almost to the exclusion of silver.

Gold coins did not circulate as much as silver coins. Surviving examples typically exhibit significantly less wear than silver. The historical evidence is thus consistent with Maynard Keynes's ideas about "money to hold" as distinct from that which was spent. The Cambridge version of the Quantity Theory

65 Lucassen, "Deep monetization and the payment of wages in Eurasia ca. 1000-1950", defines it as requiring "a substantial (per capita equal to between five and ten times the prevailing hourly wage) stock of currencies in circulation, consisting of denominations equalling the value of one hour or less of waged work".

66 Medieval silver coins are typically much more worn in circulation than gold coins, suggesting they had a more active role in the currency. Mayhew, "Quantity theory of money". It is generally true that lower-denomination coins and notes become more worn in use than higher denominations. Even today dollar bills and five-pound notes become much more worn than higher-value notes.

67 Hotson and Mills, "London's market for bullion and specie in the eighteenth century"; and Casson and Casson, "Modelling the medieval economy". 
introduced the concept of $\mathrm{k}$, demand for money to hold, as the reciprocal of $\mathrm{v}$ in the Fisher version. ${ }^{68}$ Money withdrawn from circulation was not available to service transactions, so the effective money stock was less than the total money stock. Hoard evidence indicates clearly that larger denominations wherever available were preferred for saving, and gold coins were larger denominations par excellence. Historical evidence suggests that Henry viI, for example, accumulated a huge quantity of gold coin effectively withdrawn from the circulating currency. ${ }^{69}$

The greater importance of silver as a circulating medium may explain why it appears to have exercised a greater influence on the behaviour of prices than gold. This could also throw light on the causes of the late medieval recession. The failure of prices and the birth rate to recover for some 150 years after the outbreak of the Black Death poses one of the great puzzles of the later medieval English economy. Since real wages for the great mass of the population were at a historically high level, it has been difficult to explain why this apparent prosperity did not translate into rising population levels. John Hatcher recognized this problem, and suggested that high real wages would only raise living standards and birth rates if work was in fact plentifully available, which he doubted. ${ }^{70}$ Yet Christopher Dyer remains convinced that 15 th-century living standards were in fact high, in which case the failure of population and the economy to grow still requires explanation. ${ }^{11}$

However, if prices were depressed by the shortage of silver, this could explain the reluctance of landowners to extend themselves. Moderately rising prices are needed to encourage entrepreneurial activity, which generates growth. In this way prices do not merely reflect the state of the economy: they actually help to drive it. Money, in turn, actively influenced prices. Annual price variation was, of course, above all the result of harvest variation, but monetary factors could and did trigger longer-term price shifts, which can be discerned over decades. Regression analyses comparing wheat prices and yields have shown that similar yields over the 13th to $15^{\text {th }}$ centuries could have resulted in significantly different prices reflecting, at least in part, the availability of, especially, silver coin. ${ }^{72}$

68 See above, p. 209 note 20.

69 In her Oxford Master's dissertation, Katherine Ball contrasted the very large sums believed to have been held in the royal Treasury with our current estimates of the total English money stock. She points out that Tudor specialists are increasingly confident that Henry held over $£ 1$ million in hand in the early years of the 16th century.

70 Hatcher, "Unreal wages".

71 Dyer, "A golden age rediscovered".

72 Mayhew, "Money and prices"; and Mayhew, "The circulation of money and the behaviour of prices in medieval and early modern England". 
Historians have long appreciated the importance of prices for economic history, but some have been strangely reluctant to recognize how money has influenced prices. Writing in 1986, John Day observed that even French historians who venerate Marc Bloch were curiously blind to his work on monetary history. ${ }^{73}$ Nor is such blindness exclusively French, for the study of money has remained a rather specialist topic among historians more widely. Perhaps the technicalities of the subject obscure the extent to which money has influenced the lives and livelihoods of men, women, and families of all classes throughout Europe. The hardship and dignity of centuries of labour has the power to move historians; the passion which still warms the pages of R.H. Tawney's Agrarian Problem in the Sixteenth Century can inspire the dream of social justice, ${ }^{74}$ the vision and humanity of Fernand Braudel's picture of ordinary life can evoke sympathy and understanding for our forebears. ${ }^{75}$ But weight standards and gold - silver ratios, die-studies and mint output figures do not quicken the pulse in quite the same way. Nevertheless, this chapter has tried to show that the dry technicalities of medieval money did bear directly upon the life chances of millions, and that a better understanding of that still has the power to change lives today.

\section{Bibliography}

Allen, M., "The first sterling area", Economic History Review 70 (2017), 79-100.

Allen, M., "Medieval English die-output", British Numismatic Journal, 74 (2004), 39-49.

Allen, M., Mints and Money in Medieval England, Cambridge, 2012.

Allen, M., "The transformation of the English coinage in the fourteenth century and the economy", paper delivered at the Twelfth Anglo-American Seminar on the Medieval Economy and Society, Stirling, 2016.

Allen, M., and Coffman, D'M. (eds.), Money, Prices and Wages: Essays in Honour of Professor Nicholas Mayhew, Basingstoke, 2015.

Allen, M., and Oddie, G., "Revised estimates of the English silver currency, 1282-1351", British Numismatic Journal 85 (2015), $238-56$.

Allen, R.C., Consumer Price Indexes, available at https://www.nuffield.ox.ac.uk/people/ sites/allen-research-pages/.

Allen, R.C., "The great divergence in European wages and prices from the middle ages to the first world war", Explorations in Economic History ${ }_{3} 8$ (2001), 411-47.

73 Day, "L'histoire de la monnaie dans les écrits de Marc Bloch", pp. 271-72.

74 Tawney, The Agrarian Problem in the Sixteenth Century.

75 Braudel, Civilisation and Capitalism. 
Allen, R.C., "The high wage economy and the industrial revolution: a restatement", Economic History Review 68 (2015), 1-22.

Armstrong, L., Elbl, I., and Elbl, M. (eds.), Money, Markets and Trade in Later Medieval Europe: Essays in Honour of John H.A. Munro, Leiden, 2007.

Bairoch, P., "Estimations du revenue national dans les sociétés occidentales preindustrielles et au XIXe siècle", Revue économique 28 (1977), 177-208.

Bolton, J., Money in the Medieval English Economy 973-1489, Manchester, 2012.

Bolton, J., "Reply to Pamela Nightingale's 'A Crisis of Credit' ", British Numismatic Journal 83 (2013), 164-65.

Bolton, J. "Was there a 'crisis of credit' in fifteenth-century England?" British Numismatic Journal 81 (2011), 144-64.

Bompaire M., and Dumas, F., Numismatique Médiévale (L'Atelier du Médiéviste, 7), Turnhout, 2000.

Braudel, F., Civilization and Capitalism, 15th-18th Century, 3 vols., London, 1985.

Briggs, C., Credit and Village Society in Fourteenth-Century England, Oxford, 2009.

Britnell, R.H., and Campbell, B.M.S. (eds.), A Commercialising Economy: England 1086 to c.130o, Manchester, 1995 .

Broadberry, S., Campbell, B., Klein, A., Ovlerton, M., and van Leeuwen, B., British Economic Growth, 1270-1870, Cambridge, 2015.

Campbell, B., "Benchmarking medieval economic development: England, Wales, Scotland, and Ireland, c.129o", Economic History Review 61 (2008), 896-948.

Casson, M., and Casson, C., "Modelling the medieval economy: money, prices and income in England, 1263-1520", in Allen and Coffman, Money, Prices and Wages, $5^{1-73}$.

Challis, C.E. (ed.), A New History of the Royal Mint, Cambridge, 1992.

Clark, G., The International Institute of Social History List of Datafiles of Historical Prices and Wages at www.iisg.nl/hpw.

Day, J., "The great bullion famine of the fifteenth century", Past \& Present 79 (1978), $3-54$.

Day, J., "L'histoire de la monnaie dans les écrits de Marc Bloch", in J. Day, Monnaies et marches au Moyen Âge, Paris, 1994, 271-81.

Desan, C., Making Money: Coin, Currency and the Coming of Capitalism, Oxford, 2014.

Dialogus De Scacario (The Course of the Exchequer), edited and translated by Charles Johnson, London, $195^{\circ}$.

Dyer, C., A Country Merchant, 1495-1520: Trading and Farming at the End of the Middle Ages, Oxford, 2012.

Dyer, C., "A golden age rediscovered: labourers' wages in the fifteenth century", in Allen and Coffman, Money, Prices and Wages, 180-95.

Dyer, C., "A note on the calculation of GDP for 1086 and 1300", in Britnell and Campbell, A Commercialising Economy, 196-98. 
Esty, W.W., "Estimation of the size of a coinage: a survey and comparison of methods", Numismatic Chronicle 146 (1986), 185-215.

Esty, W.W., "How to estimate the original number of dies and coverage of a sample", Numismatic Chronicle 166 (2006), 359-64.

Farmer, D.L., "Prices and wages", in H.E. Hallam (ed.), The Agrarian History of England and Wales, Vol. 2: 1042 to 1350, Cambridge, 1988, 715-817.

Farmer, D.L., "Prices and wages, 1350-1500", in E. Miller (ed.), The Agrarian History of England and Wales, Vol. 3: 1348 to 1500, Cambridge, 1991, 431-525.

Fisher, I., The Purchasing Power of Money: Its Determination and Relation to Credit, Interest and Crises, New York, 1911.

Flynn, D., "Use and misuse of the quantity theory of money in early modern historiography”, in E. van Cauwenberghe and F. Irsigler, (eds.), Münzprägung, Geldumlauf und Wechselkurse: Proceedings of the 8th International Economic History Congress, sect. C7, Budapest, 1982, 382-418.

Fox, D., and Ernst, W. (eds.), Money in the Western Legal Tradition: Middle Ages to Bretton Woods, Oxford, 2016.

Gillingham, J.B., "Chronicles and coins as evidence for levels of tribute and taxation in late tenth- and early eleventh-century England", English Historical Review 105 (1990), 939-50.

Gillingham, J.B., “'The most precious jewel in the English crown': levels of danegeld and heregeld in the early eleventh century", English Historical Review 104 (1989), $373-84$.

Grierson, P., "Commerce in the dark ages: a critique of the evidence", Transactions of the Royal Historical Society, 5th ser., 9 (1959), 123-40.

Harvey, S., Domesday: Book of Judgement, Oxford, 2014.

Hatcher, J. "Unreal wages: long-run living standards and the 'golden age' of the fifteenth century”, in B. Dodds and C.D. Liddy (eds.), Commercial Activity, Markets and Entrepreneurs in the Middle Ages: Essays in Honour of Richard Britnell, Woodbridge, 2011, 1-24.

Hotson, A., "English Mint Prices for Silver and Gold", available at https://oxford.academia.edu/AnthonyHotson.

Hotson, A., Respectable Banking: The Search for Stability in London's Money and Credit Markets since the Great Currency Crisis of 1695, Oxford, forthcoming.

Hotson, A., and Mills, T., "London's market for bullion and specie in the eighteenth century: the roles of the London mint and the bank of England in the stabilization of prices", in Allen and Coffman, Money, Prices and Wages, 211-27.

Jenkinson, H. "Exchequer tallies", Archaeologia 62 (1911), 367-8o.

Jenkinson, H. "Medieval tallies, public and private", Archaeologica 74 (1925), 289-351.

Kirby, J., The Plumpton Letters and Papers, Camden Fifth Series 8, Cambridge, 1996. 
Langdon, J., and Masschaele, J., "Commercial activity and population growth in medieval England”, Past \& Present 190 (2006), 35-81.

Lawson, M.K., "The collection of danegeld and heregeld in the reigns of Aethelred II and Cnut", English Historical Review 99 (1984), 721-38.

Lawson, M.K., “Danegeld and heregeld once more”, English Historical Review 105 (1990), 951-61.

Lawson, M.K., “'Those stories look true': levels of taxation in the reigns of Aethelred II and Cnut", English Historical Review 104 (1989), 385-406.

Le Goff, J., Money and the Middle Ages, Cambridge, 2012.

Lennard, R.W., Rural England, 1086-1135, Oxford, 1966.

Lloyd, T.H., The English Wool Trade in the Middle Ages, Cambridge, 1977.

Lloyd, T.H., "Overseas trade and the English money supply in the fourteenth century", in N.J. Mayhew (ed.), Edwardian Monetary Affairs (1279-1344), Oxford, 1977, 96-124.

Lucassen, J., "Deep monetization and the payment of wages in Eurasia ca. 1000-1950", in R.J. van der Spek (ed.), Coins, Currencies and Crises: On Money and Trust from c.200o $B C-c . A D 2000$, forthcoming.

Maddicott, J., "The English peasantry and the demands of the crown", Past \& Present supplement 1 (1975), 1-75.

Mate, Mavis, "The role of gold coinage in the English economy, 1338-1400," Numismatic Chronicle, 7 th ser., 18 (1978), 126-41.

Mayhew, N. "The circulation of money and the behaviour of prices in medieval and early modern England", in B. van Leeuwen and J. Luiten van Zanden (eds.), A History of Market Performance from Ancient Babylonia to the Modern World, London, 2014, 598-632.

Mayhew, N. "Modelling medieval monetisation", in Britnell and Campbell, A Commercialising Economy, 55-77.

Mayhew, N., "The monetary background to the Yorkist recoinage of 1464-71", British Numismatic Journal 44 (1974), 62-73.

Mayhew, N., "Monetary policy in medieval Britain and Ireland and its possible economic consequences", paper delivered at the Twelfth Anglo-American Seminar on the Medieval Economy and Society, Stirling, 2016.

Mayhew, N., "Money and prices in England from Henry II to Edward III", Agricultural History Review 35 (1987), 121-32.

Mayhew, N., "Money in England from the middle ages to the nineteenth century", in R.J. van der Spiek (ed.), Coins, Currencies and Crises: On Money and Trust from c. 2000 $B C-c . A D 2000$, forthcoming.

Mayhew, N., "Numismatic evidence and falling prices in the fourteenth century", Economic History Review 27 (1974), 1-15.

Mayhew, N., "Population, money supply, and the velocity of circulation in England, 1300-170o", Economic History Review 48 (1995), 238-57. 
Mayhew, N., "Prices in England, 1170-175o", Past \& Present 219 (2013), 3-39.

Mayhew, N., "The quantity theory of money: 3. velocity", Numismatic Chronicle 172 (2012), 397-403.

Mayhew, N. "The quantity theory of money in historical perspective", in M. Casson and N. Hashimzade (eds.), Large Databases in Economic History: Research Methods and Case Studies, Abingdon, 2013, 62-96.

Metcalf, D.M., "How large was the Anglo-Saxon currency?", Economic History Review, 2nd ser., 18 (1965), 475-82.

Metcalf, D.M., "Thrymsas and sceattas and the balance of payments", in R. Naismith, M. Allen, and E. Screen (eds.), Early Medieval Monetary History: Studies in Memory of Mark Blackburn, Farnham, 2014, 243-56.

Metcalf, D.M., Thrymsas and Sceattas in the Ashmolean Museum Oxford, 3 vols., London, 1993-1994.

Metcalf, D.M., and Op den Velde, W., The Monetary Economy of the Netherlands c.69oc.76o and Trade with England: A Study of the 'Porcupine' Sceattas of Series E (Jaarboek voor Munt-en Penningkunde, 96-97), Amsterdam 20o9-2010.

Miskimin, H.A., "Missing bullion or missing documents: a rejoinder", Journal of European Economic History 20 (1991), 673-75.

Miskimin, H.A., Money and Power in Fifteenth-Century France, New Haven, 1984.

Miskimin, H.A., Money, Prices and Foreign Exchange in Fourteenth-Century France, New Haven, 1963 .

Munro, J.H.A., "Bibliography of works", in Armstrong, Elbl, and Elbl, Money, Markets and Trade, 2007, 11-40.

Munro, J.H.A., “'Money, prices, wages, and 'profit inflation' in Spain, the southern Netherlands, and England during the price revolution era, ca. 1520-ca. 1650", História e Economia: Revista Interdisciplinar 4 (2008), 13-71.

Munro, J.H.A., "The technology and economics of coinage debasements", in J.H. Munro (ed.), Money in the Pre-Industrial World, London, 2012, 15-32.

Naismith, R., Money and Power in Anglo-Saxon England: The Southern English Kingdoms 757-865, Cambridge, 2012.

Nightingale, P., "A crisis of credit in the fifteenth century or of historical interpretation", British Numismatic Journal 83 (2013), 149-63.

Nightingale, P., "The English parochial clergy as investors and creditors in the first half of the fourteenth century", in P. Schofield and N. Mayhew (eds.), Credit and Debt in Medieval England, Oxford, 2002, 89-105.

Nightingale, P., "Gold, credit and mortality: distinguishing deflationary pressures on the late medieval English economy", Economic History Review, 2nd ser., 63 (2010), 1081-1104.

Nightingale, P., "Knights and merchants: trade, politics and the gentry in late medieval England", Past \& Present 169 (2000), 36-62. 
Nightingale, P., "Monetary contraction and mercantile credit in later medieval England", Economic History Review, 2nd ser., 43 (1990), 56o-75.

Nightingale, P., Trade, Money and Power in Medieval England, Aldershot, 2007.

Op den Velde, W., and Metcalf, D.M., The Monetary Economy of the Netherlands c.69oc.715 and the Trade with England: a Study of the Sceattas of Series D (Jaarboek voor Munt en Penningkunde, 9o), Amsterdam, 2003.

Palma, N. "Reconstruction of annual money supply over the long run: the case of England, 1279-1870", Economic History Review 71 (2018), 373-92.

Phelps Brown, E.H., and Hopkins, S., "Seven centuries of the prices of consumables, compared with builders' wage-rates", in E.M. Carus-Wilson (ed.), Essays in Economic History, vol. 2, London, 1962, 179-207.

Postan, M.M., Medieval Trade and Finance, Cambridge, 1973.

Postan, M.M., "Note”, Economic History Review, 2nd ser., 12 (1959), 77-82.

Postan, M.M., "The rise of a money economy", in M.M. Postan, Essays on Medieval Agriculture and General Problems of the Medieval Economy, Cambridge, 1973, 28-40.

Rogers, J.E.T., A History of Agriculture and Prices in England, 1259-1793, 7 vols, Oxford, 1866-1902.

Rogers, J.E.T., Six Centuries of Work and Wages: The History of English Labour, London, 1890.

Sawyer, P.H., The Wealth of Anglo-Saxon England, Oxford, 2013.

Sawyer, P.H., "The wealth of England in the eleventh century", Transactions of the Royal Historical Society, 5 th ser., 15 (1965), 145-64.

Sellwood, D., "Medieval minting techniques", British Numismatic Journal 31 (1962), $57-65$.

Skidelsky, R., John Maynard Keynes: The Economist as Saviour, 1920-1937, London, 1992.

Snooks, G.D., "The dynamic role of the market in the Anglo-Norman economy and beyond, 1086-1300", in Britnell and Campbell, A Commercialising Economy, 27-54.

Spufford, P., "Debasement of the coinage", in J.H. Munro (ed.), Money in the PreIndustrial World, London, 2012, 63-86.

Spufford, P., Money and Its Use in Medieval Europe, Cambridge, 1988.

Stevens, M.F., "London creditors and the fifteenth-century depression", Economic History Review 69, (2016), 1083-1107.

Sussman, N., "Missing bullion or missing documents: a revision and reappraisal of French minting statistics, 1385-1415", Journal of European Economic History 19 (1990), 147-61.

Sussman, N. "A reply", Journal of European Economic History 20 (1991), 677-82.

Tawney, R.H., The Agrarian Problem in the Sixteenth Century, London, 1912.

Walker, J.T., "National income in domesday England", in Allen and Coffman, Money, Prices and Wages, 24-50. 
Watson, A.M., "Back to gold-and silver", Economic History Review, 2nd ser., 20 (1967), $1-34$.

Wordie, J.R., "Deflationary factors in the Tudor price rise", Past \& Present 154 (1997), $32-70$.

Websites, Etc.

Corpus of Early Medieval Coin Finds at http://www.fitzmuseum.cam.ac.uk/dept/ coins/emc.

Netherlands finds database at http://www.dnb.nl/over-dnb/nationale-numismatische -collectie/numis/index.jsp.

Portable Antiquities Scheme finds database available at https://finds.org.uk/. 